This item was submitted to Loughborough's Research Repository by the author.

Items in Figshare are protected by copyright, with all rights reserved, unless otherwise indicated.

\title{
A multilevel perspective to the study of export venture performance
}

\section{PLEASE CITE THE PUBLISHED VERSION}

https://doi.org/10.1108/IMR-12-2016-0213

\section{PUBLISHER}

(c) Emerald

\section{VERSION}

AM (Accepted Manuscript)

\section{PUBLISHER STATEMENT}

This work is made available according to the conditions of the Creative Commons Attribution-NonCommercialNoDerivatives 4.0 International (CC BY-NC-ND 4.0) licence. Full details of this licence are available at: https://creativecommons.org/licenses/by-nc-nd/4.0/

\section{LICENCE}

CC BY-NC-ND 4.0

\section{REPOSITORY RECORD}

Oliveira, Joao, and John Cadogan. 2019. "A Multilevel Perspective to the Study of Export Venture Performance”. figshare. https://hdl.handle.net/2134/23497. 


\section{Title of the manuscript:}

A multilevel perspective to the study of export venture performance

\section{Authors}

João S. Oliveira

Assistant Professor (Lecturer), School of Business and Economics, Loughborough University, Loughborough, UK

Main research interests: marketing strategy, international marketing

Postal address: School of Business and Economics, Loughborough University, Loughborough,

Leicestershire, LE11 3TU, UK

Email address: J.Oliveira@lboro.ac.uk

Tel.: +44 (0)1509 228846

Fax: $+44(0) 1509223960$

John W. Cadogan

$\mathrm{PhD}$ in International Marketing Strategy, Wales, UK

Professor of Marketing, School of Business and Economics, Loughborough University,

Loughborough, UK

Honorary Professor of Marketing and Docent at Lappeenranta University of Technology (LUT), Finland

Main research interests: marketing strategy, international marketing and sales

Postal address: School of Business and Economics, Loughborough University, Loughborough, Leicestershire. LE11 3TU, UK

Email: J.W.Cadogan@lboro.ac.uk

Tel.: +44 (0)1509 228846

Fax: $+44(0) 1509223960$

\section{Suggestions for short running title:}

Multilevel export performance research

Multilevel models of export performance

\section{Places where the paper was presented:}

An earlier version of this paper was presented at the 2013 AMA Winter Marketing Educators' Conference, February 15-17, Las Vegas, USA. 


\section{Title of the manuscript:}

A multilevel perspective to the study of export venture performance

Purpose: We present several opportunities that can emerge from using a multilevel approach to study the antecedents of export venture performance, and provide scholars with the conceptual and practical tools for developing multilevel models of export venture success.

\section{Design/methodology/approach: Essay.}

Findings: The paper shows the problems which scholars face if they continue to engage in using single venture data to test models that are inherently multilevel in nature.

Research limitations/implications: There may be a need to revisit previous works that utilize samples of single ventures to assess models of export venture performance that are implicitly multilevel.

Practical implications: The paper outlines the practical issues that researchers need to consider when conducting multilevel research in the export venture performance field.

Originality/value: The paper is the first to focus on the multilevel nature of the export venture performance construct.

Keywords: Multilevel Analysis; Levels of Analysis; Export Marketing; Export Venture Performance; Export Venture; Export Function 


\section{INTRODUCTION}

Many researchers are interested in developing and testing models of the antecedents of export performance. Existing studies typically examine the predictors of export performance either from the export function level of analysis or from the export venture level of analysis (Oliveira, Cadogan, \& Souchon, 2012; Chen, Sousa and He, 2016). Investigations carried out at the export function level of analysis focus on the overall export performance attained by the entire exporting entity (e.g., Aulakh, Kotabe, \& Teegen, 2000; Brouthers \& Xu, 2002; Cadogan, Kuivalainen, \& Sundqvist, 2009; Dhanaraj \& Beamish, 2003; He, Brouthers, \& Filatotchev, 2013; Dow, 2006; Papadopoulos, \& Martín Martín, 2010). For instance, these studies may seek to identify the causes of managers' satisfaction with the firm's export sales performance, or uncover the drivers of the firm's export profit growth.

Studies pursued at the single export venture level of analysis, on the other hand, focus on the performance of a specific (typically only a single) export venture within the entire exporting entity (e.g., Cavusgil \& Zou, 1994; Katsikeas, Samiee, \& Theodosiou, 2006; Lages, Jap, \& Griffith, 2008; Morgan, Kaleka, \& Katsikeas, 2004; Morgan, Katsikeas, \& Vorhies, 2012), where an export venture is defined as a single product or product line exported by a company to a specific foreign market (Cavusgil \& Zou, 1994; Morgan et al., 2004). Here, the researchers are not explicitly interested in the big picture of firm level success, but seek only to study the factors that might enhance the performance of the specific venture in question.

Yet, the export function and the export venture levels of analysis are inherently related, as firms' export functions can be thought of as portfolios composed of those firms' multiple export ventures (Katsikeas, Leonidou, \& Morgan, 2000; Madsen, 1998). Export activity (and, hence, export performance) is, therefore, a multilevel phenomenon, with a firm's export function being the higher level unit and its export ventures being the lower level units nested within the firm's export function (Oliveira et al., 2012). Now of course, some firms may have only one export venture: however, our experience indicates that the latter is relatively rare. Indeed, it is not infrequent for small to mediumsized exporting firms to operate in dozens of export ventures, even hundreds. 
Following from this, it can be argued that the practice of focusing on the performance of only a single venture in any one firm is somewhat dangerous, since it might lead to invalid recommendations for practicing managers. For instance, an export venture (V1) might perform at very high standard, and have very high sales growth figures: however, V1's performance might come at the expense of the performance of the firm's other export ventures, which are under-invested in, and so do not reach their performance potential. Accordingly, the causes of V1's strong performance may also be causes of the firm's overall decline in export success. Without a multilevel perspective, in which the firm's various ventures are explicitly modelled as units that need adequate sampling, studies of export venture performance may produce biased pictures of the real impacts of variables on the overall outcomes of the firm.

Accordingly, the purposes of the current study to highlight the dangers and biases that may arise when drawing conclusions about the determinants of export venture success without explicitly accommodating multilevel thinking, and to encourage the use of multilevel perspectives in the study of export venture performance. To this end, we present the structure of multilevel models and show how they can be used to answer questions which may be important for export performance researchers using export marketing examples. We then highlight some of the potential pitfalls one may encounter if one does not use multilevel models when investigating the antecedents of export venture performance. Subsequently, we focus on the practical nature of conducting multilevel modelling, by discussing the choices researchers will need to make when carrying-out multilevel export venture performance investigations. Key issues include sample size decisions, the centering of variables, and statistical package choice.

\section{STRUCTURE OF MULTILEVEL MODELS}

An export venture is a single product or product line exported by a company to a specific foreign market (Cavusgil \& Zou, 1994; Morgan et al., 2004). Exporting is, therefore, a multilevel phenomenon, where a firm's multiple export ventures are the lower level units nested within the firm's export function (the function that contains or manages all the firm's exporting activities), which is the higher level unit. To help demonstrate how multilevel models are typically structured, and to illustrate 
how they can be used to answer questions which may be important for export performance researchers, we first outline a set of hypothetical research questions and subsequently present a multilevel model that could be adopted to examine those questions (cf. Hofmann, 1997). Thus, for the purposes of illustration only, let us assume that a researcher postulates the following hypotheses:

H1: The extent to which an export venture's marketing strategy is adapted (export venture marketing strategy adaptation - Katsikeas et al., 2006) predicts export venture performance;

H2: The extent to which an exporting firm is market oriented (the export function's market orientation - Cadogan, Diamantopoulos, \& de Mortanges, 1999; Cadogan, Diamantopoulos, \& Siguaw, 2002), also predicts export venture performance; and

H3: The stronger the export function's market orientation, the stronger the relationship between export venture marketing strategy adaptation and export venture performance.

Equations (1), (2) and (3) provide the structure of a simple multilevel model. Here, export venture marketing strategy adaptation resides at the lowest level of analysis (Level 1), relative to export function market orientation, which resides at the export function level, a higher level of analysis (Level 2). Thus, a two-level model can be used to model the hypothesized relationships (e.g., Raudenbush \& Bryk, 2002; Snijders \& Bosker, 2012). This kind of multilevel model includes separate models for each of the two levels of analysis. The Level 1 model contains dependent and independent variables at the lower level of analysis (i.e., the variables residing at the export venture level). The Level 2 model comprises the independent variables residing at the higher level of analysis (i.e., the predictors residing at the export function level), and dependent variables residing at the lower (export venture) level of analysis. Importantly, in a two-level model, the Level 1 model is estimated separately for each Level 2 unit. Hence, in the present example, the Level 1 model would be estimated separately for each firm (i.e., for each Level 2 unit). The Level 1 and Level 2 models would typically be specified as follows (cf. Hofmann, 1997; Peterson, Arregle, \& Martin, 2012):

Level 1 model: $\quad$ Ventperf $_{i j}=\beta_{0 j}+\beta_{1 j} *\left(\right.$ Adapt $\left._{i j}\right)+r_{i j}$ 
Level 2 model: $\quad \beta_{0 j}=\gamma_{00}+\gamma_{01}\left(\mathrm{EMO}_{j}\right)+\mathrm{u}_{0 j}$

$$
\beta_{1 j}=\gamma_{10}+\gamma_{11}\left(\mathrm{EMO}_{j}\right)+\mathrm{u}_{1 j}
$$

Where:

Ventperf $_{i j}=$ performance of export venture $i$ of firm $j$

Adapt $_{i j}=$ degree of marketing strategy adaptation pursued in export venture $i$ of firm $j$

$\beta_{0 j}=$ intercept term, estimated separately for each firm; $\beta_{0 j}$ is computed as the mean value for export venture level performance across the firm's export ventures

$\beta_{1 j}=$ slope term, estimated separately for each firm

$\mathrm{EMO}_{j}=$ degree of "export function level market orientation" of firm $j$

$\gamma_{00}=$ Level 2 intercept

$\gamma_{01}=$ Level 2 slope

$\gamma_{10}=$ Level 2 intercept

$\gamma_{11}=$ Level 2 slope

$\mathrm{r}_{i j}=$ Level 1 residual variance

$\mathrm{u}_{0 j}=$ residual variance in Level 2 intercept

$\mathrm{u}_{1 j}=$ residual variance in Level 2 slope

The Level 1 model hypothesizes that export venture level performance is positively related to export venture level marketing strategy adaptation (H1), and can be formulated using equation (1). Four possible patterns can emerge when the Level 1 model is estimated separately for each export firm. Such patterns are depicted in Figure 1.

(Figure 1 goes about here)

Figure 1a illustrates the situation in which the regression lines are identical for all firms' export functions (this is illustrated by the juxtaposition of the regression lines of the various firms). 
Figure 1b illustrates the case where the regression lines of the different firms have different intercepts $\left(\beta_{0 j}\right)$, but identical slopes $\left(\beta_{1 j}\right)$. Accordingly, although the relationship between export venture marketing strategy adaptation (Adapt) and export venture performance (Ventperf) is equivalent across firms, the average venture performance level (the intercept $\beta_{0 j}$ ) differs across firms.

Figure 1c illustrates the case where the various firms have the same intercept $\left(\beta_{0 j}\right)$, but different slopes, $\left(\beta_{1 j}\right)$. Hence, although the average value of export venture performance is the same across firms when venture level adaptation levels are zero, the direction and/or strength of the relationships between export venture marketing strategy adaptation and export performance vary across firms.

Figure 1d shows the situation where both the intercept and the slope terms vary across firms. Thus, the mean value for average value of export venture performance differs across firms when venture level adaptation levels are zero, and the direction and/or strength of the relationships between export venture marketing strategy adaptation and export performance vary across firms.

The Level 2 model then seeks to investigate why there are, potentially, differences in the Level 1 model intercepts and/or slope terms, and can be formulated using equations (2) and (3). Accordingly, the dependent variables of the Level 2 model are $\beta_{0 j}$, the intercept for the Level 1 model, and $\beta_{1 j}$, the slope for the Level 1 model. The independent variables in the Level 2 model reside at the higher level of analysis (here, at the level of the firm's export function). In this example, the researcher is interested in studying the export function's market orientation as a potential cause of both the differences in the mean value of export venture performance (H2), and in the differences in the relationships between export venture marketing strategy adaptation and export venture performance, observed across the firms in the Level 1 model (H3).When assessing a multilevel model of this kind, in order for those three hypotheses to be corroborated, there are a number of conditions that need to be met (cf. Hofmann, 1997). Specifically, H1 states that export venture marketing strategy adaptation predicts export venture performance. Thus, if $\mathrm{H} 1$ is to be supported, one must see significant systematic variance across export venture performance within firms, and export venture marketing strategy adaptation must predict this variance in export venture performance. Thus, $\beta_{1 j}$ should be positive and significant in (1). 
$\mathrm{H} 2$ states that export function market orientation predicts venture performance, and if $\mathrm{H} 2$ is to be supported, one expects to see significant systematic variance in export venture performance across firms' export functions, and to see export function market orientation predicting (covarying with) the mean value of export venture performance across firms. For this reason, one expects a significant and positive $\gamma_{01}$ coefficient in (2).

H3 states that the stronger the export function's market orientation, the stronger the relationship between export venture marketing strategy adaptation and export venture performance. Accordingly, support for $\mathrm{H} 3$ is provided (a) if there is significant variation across firms in terms of the relationship between export venture marketing strategy adaptation and export venture performance, and (b) if variance in export function market orientation significantly predicts variances in the strength of the relationship between export venture marketing strategy adaptation and export venture performance $\left(\beta_{1 j}\right)$. Thus, H3 is supported if a positive and significant $\gamma_{11}$ coefficient is obtained in (3). In the above, and for the purposes of illustration only, we outline the basic structure of a simple multilevel model containing only one Level 1 predictor, export venture marketing strategy adaptation, and only one Level 2 predictor, export function market orientation. However, the logic and equations extent to the multivariate situation where there are multiple Level 1 and / or Level 2 variables, and to situations where there are more than two levels. We now pinpoint the perils of not adopting a multilevel perspective when examining the antecedents of export success.

\section{THE PROBLEM OF SAMPLING ONE VENTURE PER FIRM IN EXPORT VENTURE PERFORMANCE RESEARCH}

Many export performance researchers investigate variables that inherently exist at the level of the firm's export function (for instance, the firm's resources and the capabilities it brings to bear in its export markets), and seek to clarify the impact of these features of the firm on the performance outcomes of export ventures (Sousa et al., 2008; Zou \& Stan, 1998). In so doing, researchers are engendering models that are implicitly of a multilevel kind, and as we show in the previous section, the causal forces implied in such a model can be explicitly coded in the regression equations to accommodate causes that occur at distinct levels in the exporting entity (the exporting firm). Critically, 
to test these models, one needs to sample across multiple ventures within the firm, and across multiple firms, in order to assess the causal hypotheses at the multiple levels at which they are specified.

One issue that becomes very obvious from an examination of the export venture performance literature, however, is that while it is common to sample across multiple exporting firms, few studies sample more than one export venture per firm. Accordingly, the literature is restricted to drawing conclusions about the nature of the causes of export venture success based on models that impose a single level analysis framework, in which the causal forces that (might) occur at levels other than the venture itself cannot be studied with precision. We explore some of these biases in the following.

To help structure the discussion, let us consider the case where a researcher is interested in studying the relationship between export venture marketing strategy adaptation and export venture performance - see equation (1). An obvious and appropriate sampling approach would require that the researcher focus on a firm, and obtain data on several of the firm's export ventures, in order to estimate equation (1). The stability of the latter finding could be assessed by repeating the process using data from additional exporting firms. By way of illustration only, let us assume the following causal reality: increases in export venture marketing strategy adaptation cause increases in export venture performance.

Figure 2, provides a pictorial representation of this pattern: in Firm 1, the regression line shows an increasing upwards shift in venture performance as venture adaptation increases. The same pattern can be seen for Firms 2, 3, and so on, for all $j$ firms. However, in Figure 2 we also see that the intercept, $\beta_{0 j}$ in equation (1), varies across exporting firms. If a researcher samples from multiple export ventures in each firm sampled, then it should be possible to identify the pattern that is obvious in Figure 2, which is that increases in export venture performance follow higher levels of export venture marketing strategy adaptation. However, what happens if only one venture per firm is sampled, not multiple ventures? For the purpose of making our point, we provide an example in which a researcher collects data from Venture 2 in Firm $1\left(V_{21}\right)$, from Venture 3 in Firm $2\left(V_{32}\right)$, from Venture 4 in Firm $3\left(\mathrm{~V}_{43}\right)$, and so on. Here, the sampling approach results in a set of data points that fall on the dotted line in Figure 2, and observing the dotted line, we can see that it provides a very biased picture of the "true" nature of the causal relationships between export venture marketing 
strategy adaptation and export venture performance. In fact, in this case, by not sampling from multiple ventures within each firm, the single venture sampling approach is simply unable to provide a true reflection of the relationship in question: there is no realistic combination of single venture samples that could possibly provide the researcher with an accurate picture of this relationship using the data points in Figure 2. This synthetic example acts to emphasize one of the potential dangers of gathering data on only a single export venture per firm.

In Figure 2, the causal reality we specify states that the relationship between export venture marketing strategy adaptation and export venture performance is positive for all firms, but that the intercept, $\beta_{0 j}$, varies across exporters. The latter condition indicates that some Level 2 feature or features of the firm (e.g., the firm's EMO) shape venture performance directly too. Of course, it could be that causality operates differently. For instance, let it be the case that the "real" relationship between export venture marketing strategy adaptation and export venture performance varies across firms, although the intercept, $\beta_{0 j}$, is constant for all exporters. Specifically, a Level 2 feature of the exporting firm (e.g., its EMO) (a) shapes the degree to which export venture marketing strategy adaptation causes export venture performance, but (b) has a constant direct impact on venture performance. Thus, in equation (2), $\gamma_{01}$ is zero, while in equation (3), $\gamma_{11}$ is non-zero. Figure 3 provides a pictorial representation of such a causal world, where the intercepts are the same across firms, but the slope terms are different.

(Figures 3 and 4 go about here)

Again, if one were to draw a sample of only one venture per exporting firm, one could not be confident that it provides a true reflection of the relationships between export venture marketing strategy adaptation and export venture performance. The dotted line in Figure 3 shows the relationship one would end up estimating using just one of the many potential data sets one might end up with. Indeed, since in the current version of the true world, the relationship between export venture marketing strategy adaptation and export venture performance varies across firms (in this case it is sometimes positive, sometimes is zero, and sometimes is negative), then a sample that relies on data 
from just a single venture within each exporting firm is simply unable to provide the information required to uncover the richness and complexity of the relationships that exist, and may give a very inaccurate picture of the true worldly relationships.

In Figure 4, we present an even more complex version of a potential true causal world. Here, EMO (a Level 2, export function level variable) causes export venture performance (a Level 1, venture level variable) to vary directly (i.e., $\gamma_{01}$ is non-zero), and causes the relationship between export venture marketing strategy adaptation and export venture performance to vary across firms (i.e., $\gamma_{11}$ is also non-zero). As in the previous causal worlds, in the current causal world, the differences in the intercepts and the differences in the slopes across exporting firms mean that if a researcher samples only a single venture from each firm, the observed relationship between export venture marketing strategy adaptation and export venture performance (see the dotted line in Figure 4) may be quite different from the true world relationships (the solid lines in Figure 4).

(Figure 4 goes about here)

The only case where sampling a single export venture per firm could produce unbiased results is illustrated in Figure 5. Here, the relationship between export venture marketing strategy adaptation and export venture performance is identical across firms, and all Level 2 variables (such as EMO) have insignificant causal impacts on $\beta_{0 j}$ and $\beta_{1 j}$ (i.e., $\gamma_{01}$ and $\gamma_{11}$ are zero). Thus, the intercept and the slope terms of the relationship between export venture marketing strategy adaptation and export venture performance are constant for all sampled exporters. Under these circumstances, examining a single export venture per firm would produce identical estimates to the ones which would be obtained from analyzing multiple ventures per firm, and would not produce bias.

(Figure 5 goes about here)

\section{DEVELOPING AND TESTING MULTILEVEL MODELS OF EXPORT VENTURE PERFORMANCE: PRACTICAL ASPECTS}

Researchers will need to make a number of practical decisions when conducting multilevel studies of export venture performance. Key aspects discussed in the following section concern sample size, centering of variables, and selection of statistical package. 


\section{Sample size}

There are not yet definite recommendations concerning what constitutes the absolute minimum sample size to adopt in multilevel models, as the literature is still evolving (Peterson et al., 2012). Accordingly, we are not able to provide export performance researchers with firm guidelines on the sample sizes they should aim for when conducting multilevel investigations of export venture performance. Thus we are limited to discussing the issues researchers need to take into account when making sample size decisions in multilevel investigations.

A peculiarity of multilevel research is that it involves multiple sample sizes. For example, a multilevel study of the predictors of export venture performance with two levels of analysis will involve a sample size at the level of the firm’s export functions (i.e., at the higher level of analysis) and a set of other samples sizes at the level of the firm's export ventures (i.e., at the lower level of analysis). Figure 6 demonstrates this. The higher level, Level 2, has a sample size of $\mathrm{j}$ and the lower level has a range of sample sizes ranging from i to $\mathrm{m}$, to $\mathrm{n}$, and to $\mathrm{p}$.

(Figure 6 goes about here)

Decisions regarding the values for $i, m, n, p$ and $j$ need to reflect a balance between statistical power and pragmatic considerations. In terms of statistical power, there are no hard-and-fast rules concerning the minimum sample sizes at each level of analysis that guarantee unbiased estimates in multilevel models, as the appropriate size at each level of analysis depends on various aspects, such as the number of predictor variables at that level of analysis, and the type(s) of effect being investigated (e.g., Peterson et al., 2012). Export venture performance researchers will also need to factor in pragmatic considerations when deciding on sample size in multilevel investigations. Studying the antecedents of business' export success often requires collecting primary data, since there is typically very little secondary data available regarding firms’ export activities, especially at the export venture level. Primary data collection is done, in many cases, by deploying surveys targeted at expert informants - typically export managers and senior company executives (Sousa et al., 2008; Zou \& Stan, 1998). 
For instance, in order to carry out a multilevel investigation of the determinants of export venture performance, a researcher may need to capture information from a sample of firms at the level of the firms' export function (e.g., the financial resources the export function has access to, the experience contained within the function, the function's organizational systems and structures, and so on). The researcher would also need to capture information at the level of the firm's export ventures (e.g., venture performance, venture strategy, venture environmental features, and so on), and this latter data would need to be collected for multiple ventures within each firm. The knock on effect is that multilevel studies of export performance are likely to require the collection of large quantities of data, and the burden for providing this information will often lie in the hands of a limited number of knowledgeable (and often rather senior) expert informants. The greater the information demands, the harder it is to collect data in general, and the greater the number of the export ventures sampled within a firm, the greater the information demands on the data providers. Given that the number of knowledgeable respondents is often limited in the case of firms' exporting operations, the feasibility of collecting data from a large sample of export ventures may be questionable, and might go some way towards explaining why samples containing data about just a single export venture dominate the export venture research field.

Therefore, when conducting multilevel studies of export venture performance, the decision concerning sample sizes will need to take into account both statistical power issues and pragmatic considerations that limit sample size at the lower level of analysis (i.e., in terms of the number of ventures per firm sampled). Fortunately, researchers tend to agree that, to a certain extent, it is possible to compensate the loss of power associated with having a smaller number of lower level units per higher level unit sampled (for instance, a lower number of ventures per firm) by increasing sample size at the higher level (in this case, by increasing the number of sampled firms). Also, a growing number of studies suggest that sample size at the higher level of analysis (in his case, the number of sampled firms) plays, overall, a more important role in determining the level of statistical power of a given multilevel study. Given that it is not always possible to gather data on more than a few ventures per firm without compromising study feasibility, this is good news. Thus, when faced with obstacles to the collection of Level 1 data from many export ventures, one option may be for researchers to aim for 
a large sample size at the higher level of analysis (for instance, by gathering data from a large number of exporting firms), while keeping sample size at the lower level relatively manageable by collecting data from a more practical number of export ventures per firm.

\section{Centering of variables}

Decisions concerning the centering of predictors residing at different levels of analysis (i.e., the choices concerning the scaling of those predictors), assume paramount importance in multilevel modelling, as such choices can affect the meaning of the coefficients which are obtained at each level (Hofmann \& Gavin, 1998; Park, 2008; Raudenbush \& Bryk, 2002). The three main centering options for Level 1 predictors are raw metric scaling, group mean centering, and grand mean centering.

Raw metric scaling of Level 1 predictors means that no centering occurs. Accordingly, the Level 1 predictors are used in their original metric. Group mean centering of Level 1 predictors means that the mean value for the predictor within the group (i.e., the mean value of the Level 1 predictor across the Level 1 units which are nested in a particular Level 2 unit) is subtracted from each Level 1 observation. To illustrate this, consider again the case where the researcher aims at studying the antecedents of export venture performance (a Level 1 outcome) using the predictors export venture marketing strategy adaptation (a Level 1 predictor) and “export function level market orientation” (Level 2 predictor). Group mean centering of the Level 1 predictor (export venture marketing strategy adaptation) would involve using the following formula (cf. Raundenbush \& Bryk, 2002):

Adapt ${ }^{\prime}{ }^{\prime}=$ Adapt $_{i j}-\overline{\text { Adapt }}_{. j}$

Where:

Adapt ${ }^{\prime}{ }^{\prime}=$ degree of marketing strategy adaptation pursued in export venture $i$ of firm $j$ (after group mean centering)

Adapt $_{\mathrm{ij}}=$ degree of marketing strategy adaptation pursued in export venture $i$ of firm $j$ (raw metric)

$\overline{\text { Adapt }}_{. j}=$ mean value for degree of marketing strategy adaptation pursued in export venture across the 
export ventures of firm $j$

Grand mean centering of Level 1 predictors means that the value corresponding to the average of group means for that Level 1 predictor across Level 2 units (i.e., the grand mean value for the Level 1 predictor) is subtracted from each Level 1 observation. Using the current example, the following formula would be used (cf. Raundenbush \& Bryk, 2002):

Adapt ${ }^{\prime}{ }^{\prime}=$ Adapt $_{i j}-\overline{\text { Adapt. }}$.

Where:

Adapt $\mathrm{t}_{\mathrm{i}}{ }^{\prime}=$ degree of marketing strategy adaptation pursued in export venture $i$ of firm $j$ (after grand mean centering)

Adapt $_{\mathrm{i}_{\mathrm{j}}}=$ degree of marketing strategy adaptation pursued in export venture $i$ of firm $j$ (raw metric) $\overline{\text { Adapt. }}=$ grand mean value for export venture level degree of marketing strategy adaptation obtained via averaging $\overline{\text { Adapt. }}_{. j}$ across all firms in the sample

Hofmann and Gavin (1998) contend the centering method for Level 1 predictors needs to be aligned with the theoretical paradigm which underpins the model being tested. In this context, in multilevel models, variables residing at Level 2 (in the case of the present example, variables at the level of the firm's export function) often are assumed to play a moderating role on the link between Level 1 predictors and Level 1 outcomes (e.g., moderate the link between export venture level antecedents and export venture performance). That is, multilevel models are typically used in studies which are underpinned by the moderational paradigm (e.g., Cole \& Bedeian, 2007; Jansen, Simsek, \& Cao, 2012; Whitener, 2001; Yang et al., 2012). In such circumstances, the researcher should adopt group mean centering for the Level 1 predictors. Thus, we recommend that multilevel studies of export performance which are rooted in the moderational paradigm adopt group mean centering for Level 1 predictors (in the case of this example, for export venture level antecedents). ${ }^{1}$ 
With regard to the centering of the Level 2 antecedents (i.e., of the export function level predictors, in the case of the present example), two main centering options are raw metric scaling and grand mean centering. In a similar fashion to the centering of Level 1 predictors, raw metric scaling of Level 2 predictors implies that no centering occurs and, thus, Level 2 predictors are used in their original scale. Group mean centering does not apply to Level 2 variables as there is only one value group element per group which corresponds to the group itself. Grand mean centering of Level 2 predictors means that the average value for the Level 2 predictor (i.e., the grand mean value for the Level 2 predictor) is subtracted from each Level 2 observation. Using the current example, the following formula would be used (cf. Raundenbush \& Bryk, 2002):

$\mathrm{EMO}_{\mathrm{j}}{ }^{\prime}=\mathrm{EMO}_{\mathrm{j}}-\overline{\mathrm{EMO}}$

Were:

$\mathrm{EMO}_{j}$ "= degree of "export function level market orientation” of firm $j$ (after grand mean centering) $\mathrm{EMO}_{\mathrm{j}}=$ degree of “export function level market orientation" of firm $j$ (raw metric) $\overline{\mathrm{EMO}} .=$ grand mean value for "export function level market orientation across, obtained via averaging $\mathrm{EMO}_{\mathrm{j}}$ across all firms in the sample

The centering of Level 2 predictors (i.e., the centering of the export function level predictors, in the case of the current example) is usually not as crucial as the centering of the Level 1 antecedents (i.e., the export venture level antecedents), because the resulting coefficients can be easily interpreted whatever the centering approach adopted. However, it is often convenient to center all the Level 2 predictors around their grand means (i.e., use grand mean centering for all Level 2 predictors) (Raudensbush \& Bryk, 2002). Therefore, in the case of the current example, the most suitable approach would be to use grand mean centering for all the export function level antecedents of the study. Hence, we recommend that researchers use grand mean centering for Level 2 predictors when conducting multilevel studies of export venture performance. 


\section{Package choice}

A third key decision which researchers will need to make when conducting multilevel investigations of export venture performance involves the choice of statistical package. The researcher may choose either to use general-purpose statistical software that allows for multilevel modelling, such as STATA, SAS or SPSS, or to adopt specialist multilevel software (e.g., HLM, MLwiN). While specialist software may be more complete in terms of some multilevel modelling features than general-purpose statistical software, some generalist software programs (e.g., STATA) are increasingly expanding their multilevel modelling features. In this context, a fundamental aspect which export venture performance researchers need to consider when choosing which statistical package to use in their multilevel investigations concerns latent constructs. More specifically, export venture performance researchers typically conceptualize export venture performance and its predictors as latent constructs (i.e., as variables that are not directly observed). Accordingly, software packages designed for the analysis of relationships among latent constructs (such as LISREL or MPlus) which also have some multilevel features that allow for multilevel modelling may have some advantages.

Alternatively, the researcher may opt to carry out hypotheses testing using specialist multilevel data analysis software (such as HLM). The latter software may, however, be more appropriate for testing models involving directly observed variables, rather than latent variables. In order to address such limitation, researchers using HLM may first need to assess the quality of their study measures using software which is designed for the assessing latent variables (covariance based structural equation modeling programs, such as LISREL, MPlus, or AMOS) prior to testing the study hypotheses using a multilevel analysis software package.

\section{DISCUSSION}

The examination of the antecedents of export venture performance has been the topic of many investigations over the past five decades. Despite this fact, there is a lack of multilevel research in the export venture performance literature, as existing investigations have been conducted from a single level perspective. This is contrast with other organisational research fields where researchers are 
increasingly adopting multilevel frameworks in their studies. Single level approaches do not account for the fact that exporting is a hierarchically ordered system where firms' ventures are lower level units which are nested within those firms’ export functions (i.e., within higher level units). Accordingly, single level models are not appropriate for the investigation of the antecedents of export venture performance, and may lead to biased results. The current paper highlights some of the pitfalls that can emerge by failing to utilise multilevel models of export venture performance, and pinpoints some of the key issues and decisions that researchers wishing to take on the challenge of multilevel export venture performance research will face. 


\section{NOTES}

${ }^{1}$ Researchers may wish to develop multilevel models of export performance which are not underpinned by the moderational paradigm, but rather by some other theoretical framework, such as the incremental or the mediational paradigms. In such circumstances, it may be suitable to use different centering approaches for the Level 1 predictors.

\section{REFERENCES}

Aulakh, P. S., Kotabe, M., \& Teegen, H. 2000. Export strategies and performance of firms from emerging economies: Evidence from Brazil, Chile, and Mexico. Academy of Management journal, 43(3): 342-361.

Brouthers, L. E., \& Xu, K. 2002. Product stereotypes, strategy and performance satisfaction: The case of Chinese exporters. Journal of International Business Studies, 33(4): 657-677.

Cadogan, J. W., Diamantopoulos, A., \& de Mortanges, C. P. 1999. A measure of export market orientation: Scale development and cross-cultural validation. Journal of International Business Studies, 30(4): 689-707.

Cadogan, J. W., Diamantopoulos, A., \& Siguaw, J. A. 2002. Export market-oriented activities: Their antecedents and performance consequences. Journal of International Business Studies, 33(3): 615626.

Cadogan, J.W., Kuivalainen, \& Sundqvist, S. 2009. Export market-oriented behavior and export performance: Quadratic and moderating effects under differing degrees of market dynamism and internationalization. Journal of International Marketing, 17(4): 71-89.

Cavusgil, S. T., \& Zou, S. 1994. Marketing strategy-performance relationship: An investigation of the empirical link in export market ventures. Journal of Marketing, 58(1): 1-21.

Chen, J., Sousa, C.M.P. \& He, X. 2016. The determinants of export performance: a review of the literature 2006-2014. International Marketing Review, 33 (5): 626-670.

Cole, M.S., \& Bedeian, A.G. 2007. Leadership consensus as a cross-level contextual moderator of the emotional exhaustion-work commitment relationship. The Leadership Quarterly, 18(5): 447-462.

Dhanaraj, C., \& Beamish, P. W. 2003. A resource-based approach to the study of export performance. Journal of Small Business Management, 41(3): 242-261. 
Dow, D. 2006. Adaptation and performance in foreign markets: Evidence of systematic underadaptation. Journal of International Business Studies, 37(2): 212-226.

He, X., Brouthers, K., \& Filatotchev, I. 2013. Resource-based and institutional perspectives on export channel selection and export performance. Journal of Management, 39(1): 27-47.

Hofmann, D. A. 1997. An overview of the logic and rationale of hierarchical linear models. Journal of Management, 23(6): 723-744.

Hofmann, D. A., \& Gavin, M. B. 1998. Centering decisions in hierarchical linear models: Implications for research in organizations. Journal of Management, 24(5): 623-641.

Jansen, J.P., Simsek, Z., \& Cao, Q. 2012. Ambidexterity and performance of multiunit contexts:

Cross-level moderating effects of structural and resource attributes. Strategic Management Journal, 33(11): 1286-1303.

Katsikeas, C. S., Leonidou, L. C., \& Morgan, N. A. 2000. Firm-level export performance assessment: Review, evaluation, and development. Journal of the Academy of Marketing Science, 28(4): 493-511. Katsikeas, C. S., Samiee, S., \& Theodosiou, M. 2006. Strategy fit and performance consequences of international marketing standardization. Strategic Management Journal, 27(9): 867-890.

Lages, L. F., Jap, S. D., \& Griffith, D. A. 2008. The role of past performance in export ventures: A short-term reactive approach. Journal of International Business Studies, 39(2): 304-329.

Madsen, T. K. 1998. Executive insights: Managerial judgment of export performance, Journal of International Marketing, 6(3): 82-93.

Morgan, N. A., Kaleka, A., \& Katsikeas, C. S. 2004. Antecedents of export venture performance: A theoretical model and empirical assessment. Journal of Marketing, 68(1): 90-108.

Morgan, N.A., Katsikeas, C.S., \& Vorhies, D.W. 2012. Export marketing strategy implementation, export marketing capabilities, and export venture performance. Journal of the Academy of Marketing Science, 40(2): 271-289.

Oliveira, J.S., Cadogan, J.W., \& Souchon, A. 2012. Level of analysis in export performance research. International Marketing Review, 29(1): 114-127.

Papadopoulos, N., \& Martín Martín, O. (2010). Toward a model of the relationship between internationalization and export performance. International Business Review, 19(4): 388-406. 
Park, H.S. 2008. Centering in hierarchical linear modelling. Communication Methods and Measures, 2(4): 227-259.

Peterson, M. F., Arregle, J.-L., \& Xavier, M. 2012. Multilevel models in international business research. Journal of International Business Studies, 43(5): 451-457.

Raudenbush, S. W., \& Bryk, A. S. 2002. Hierarchical linear models, (2nd ed.). Thousand Oaks, CA: Sage.

Snijders, T.A. \& Bosker, R.J. 2012. Multilevel Analysis: An introduction to basic and advanced multilevel modeling, (2nd ed.). London: Sage.

Sousa, C.M.P., Martínez-López, F.J., \& Coelho, F. 2008. The determinants of export performance: A review of the research in the literature between 1998 and 2005. International Journal of Management Reviews, 10(2): 343-374.

Whitener, E.M. 2001. Do “high commitment” human resource practices affect employee commitment? A cross-level analysis using hierarchical linear modelling. Journal of Management, 27(5): 515-535.

Yang, L.-Q. et al. 2012. Individualism-collectivism as a moderator of the work demands-strains relationship: A cross-level and cross-national examination. Journal of International Business Studies, 43(4): 424-443.

Zou, S., \& Stan, S. 1998. The determinants of export performance: A review of the empirical literature between 1987 and 1997. International Marketing Review, 15(5): 333-356. 
Figure 1. Four possible patterns for intercepts and slopes when Level 1 equation is estimated separately for each firm.

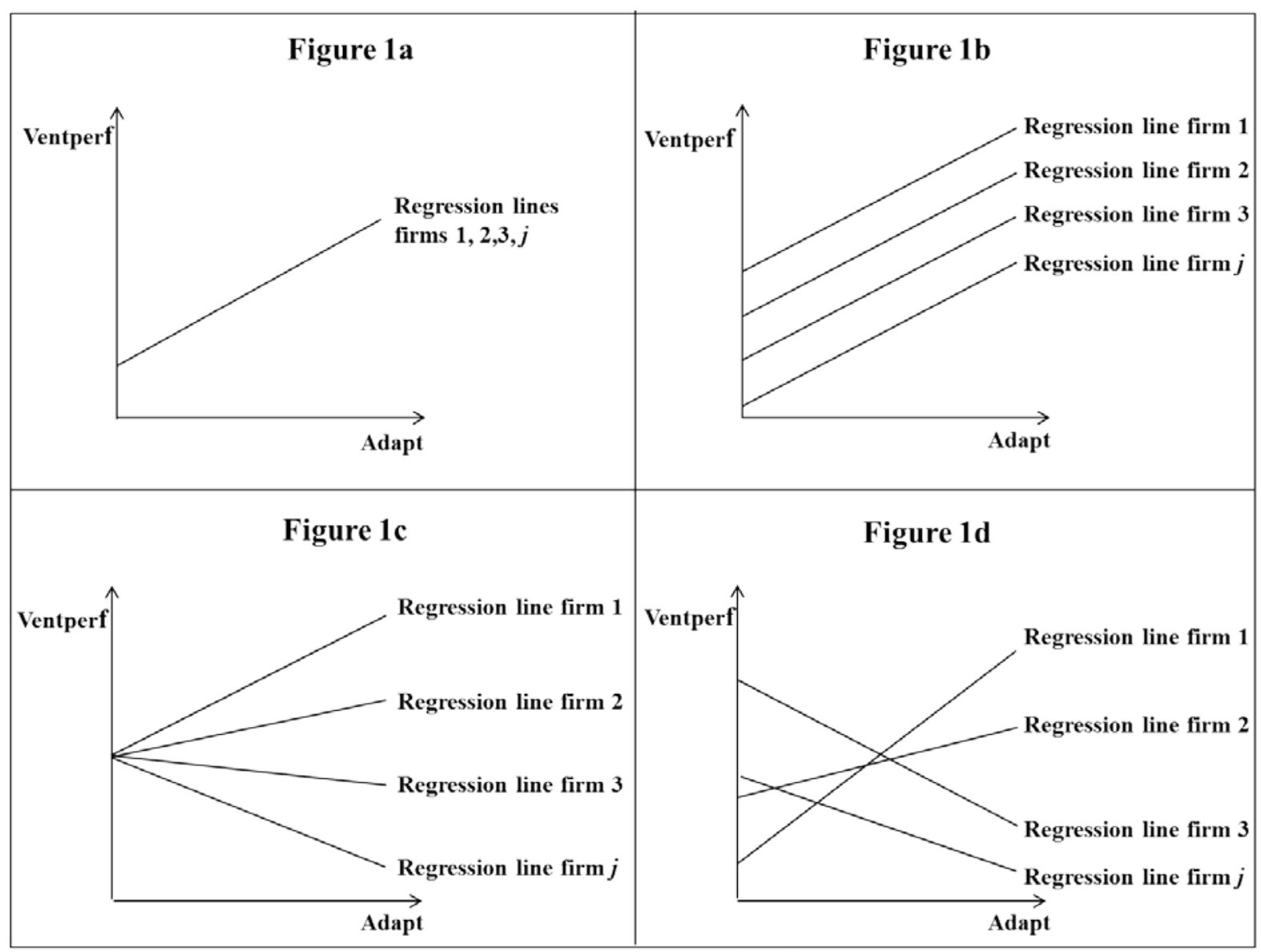


Figure 2. Relationship between export venture level marketing strategy adaptation and export venture performance: different intercept terms across firms.

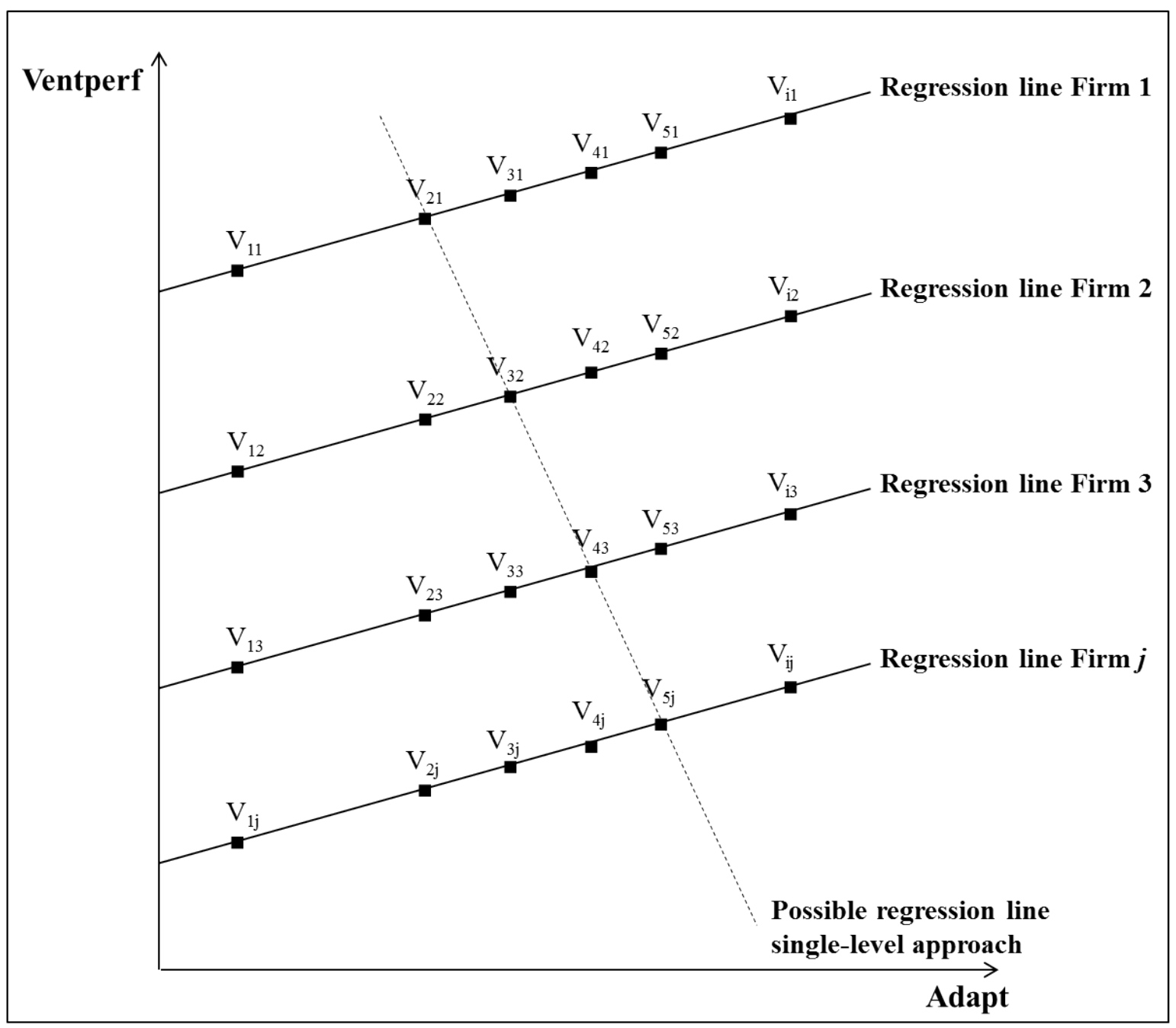


Figure 3. Relationship between export venture level marketing strategy adaptation and export venture performance: different slope terms across firms.

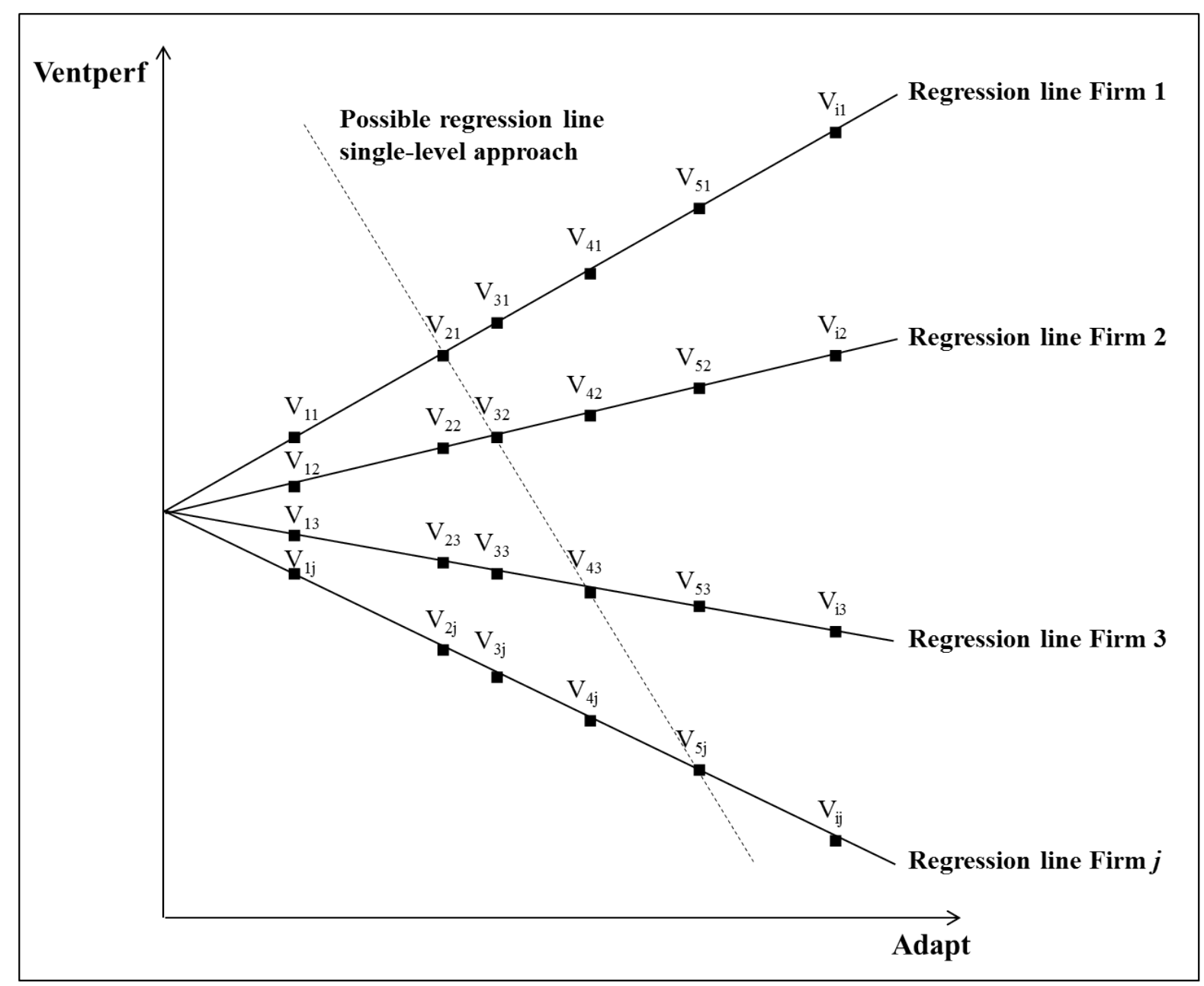


Figure 4. Relationship between export venture marketing strategy adaptation and export venture performance: different intercept and slope terms across firms.

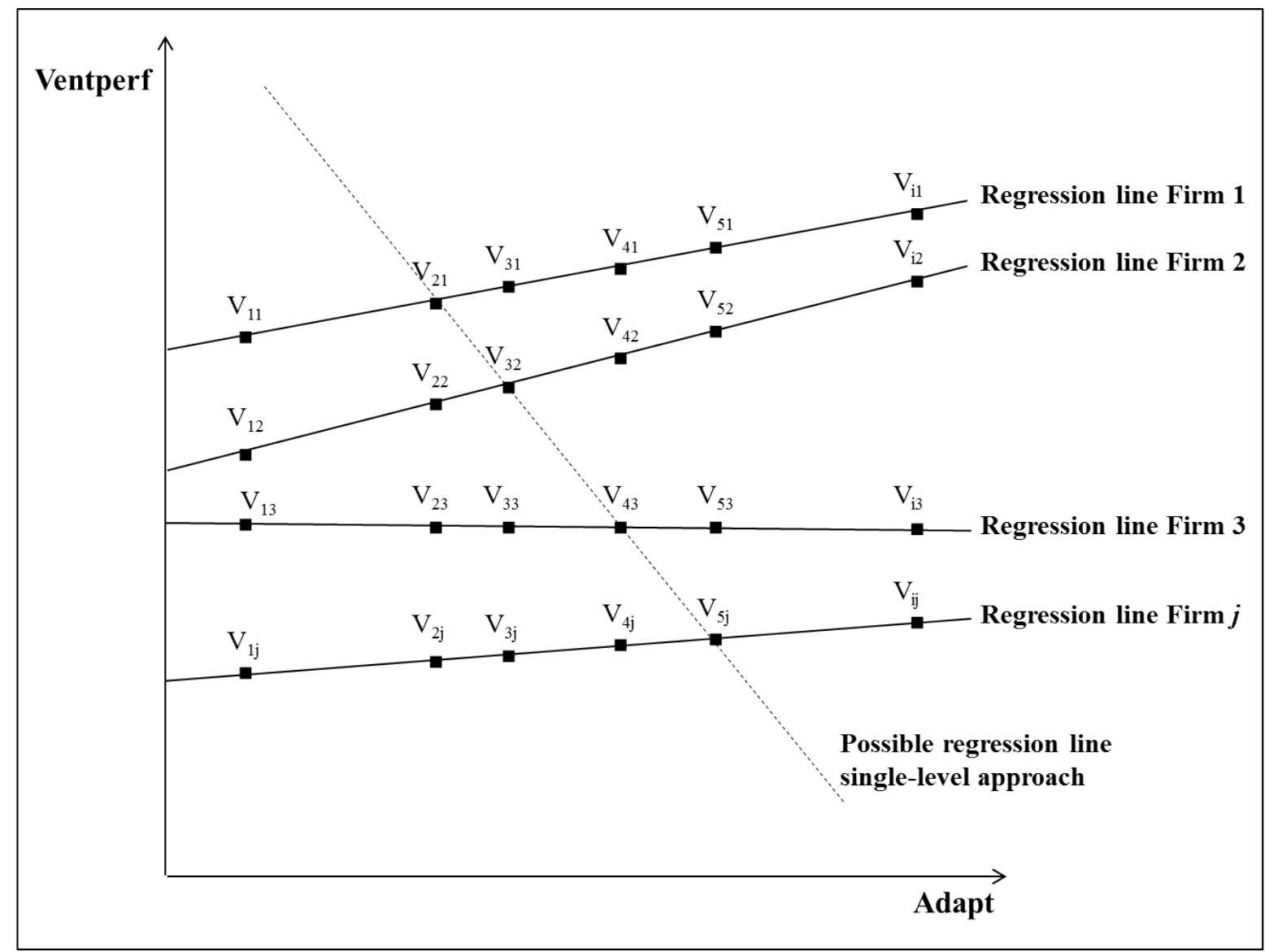


Figure 5. Relationship between export venture level marketing strategy adaptation and export venture performance: identical intercept and slope terms across firms

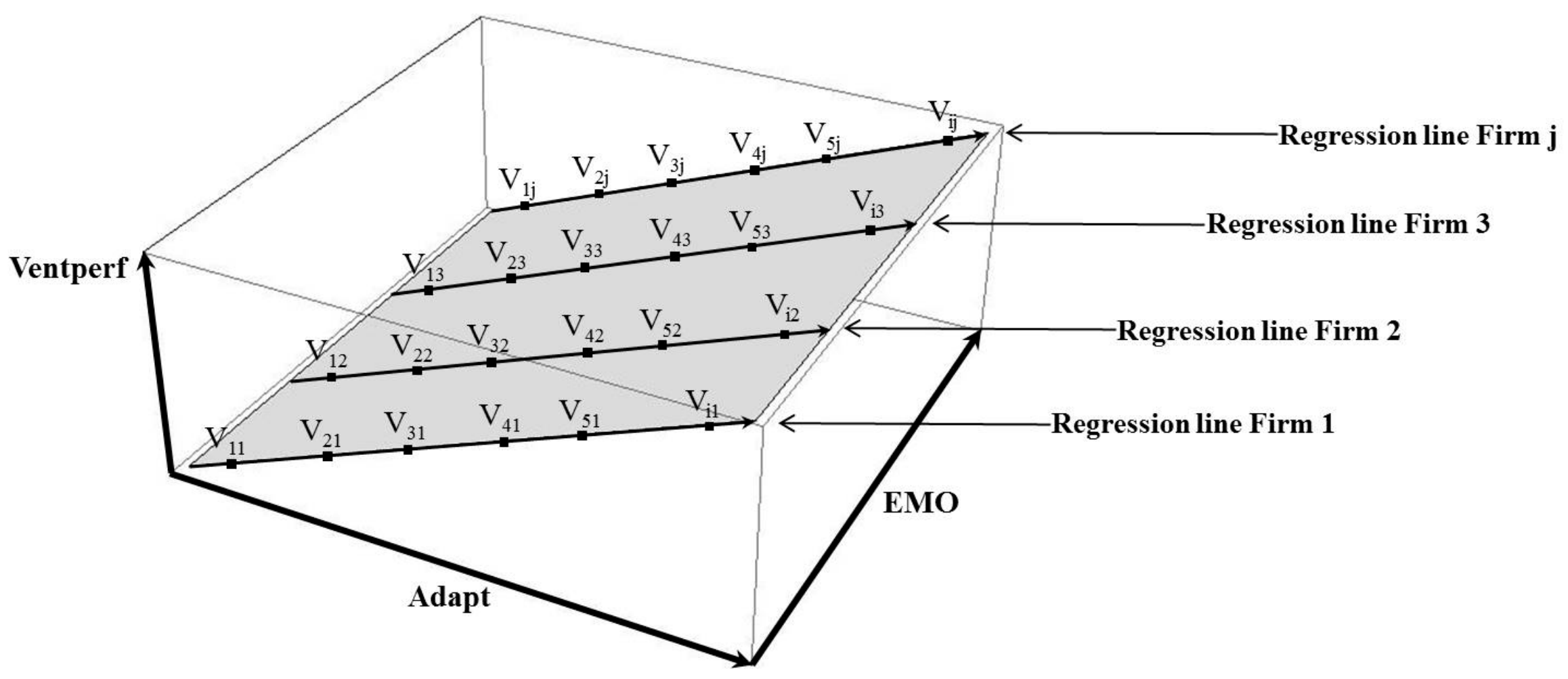


Figure 6. Data structure in multilevel export performance research: an illustration

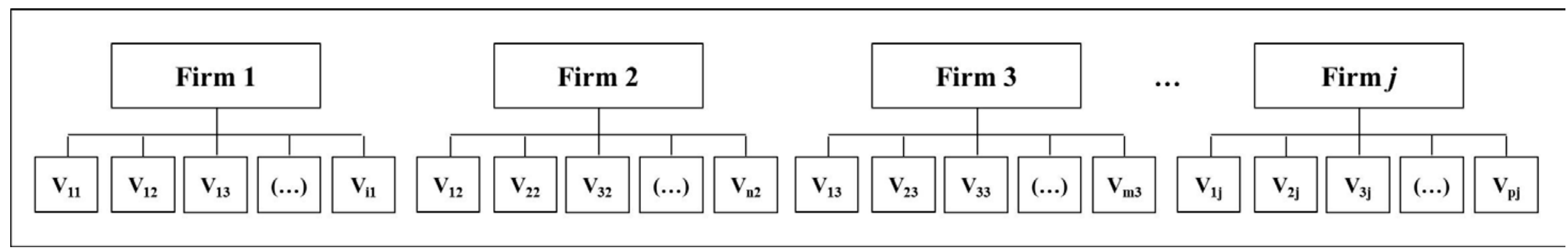

